\title{
Effect of Business Performance and Working Culture on Consumer Buying Decisions During Pandemic Covid-19
}

\author{
Nur Anisa \\ Master of Management Student Mercu Buana University \\ Jakarta Indonesia
}

\begin{abstract}
This research aims to analyze the impact of business performance and working culture on small Micro Units (MSME) on the decision of consumer purchasing in the middle of pandemic Covid-19, which is happening today. The condition of Pandemic Covid19 is very influential on the economy in Indonesia in every sector of business is no exception to existing MSME. This research was conducted by spreading a questionnaire of 122 respondents. The study uses a descriptive method and quantitative approach; the data obtained is analyzed using multiple linear regression methods with the SPSS Statistic 25 application. The results of this research showed that the influence of business performance and working culture in MSME has a significant influence on the decision of consumer purchase in the middle of pandemic Covid-19.
\end{abstract}

Keywords:- Business Performance, Work Culture, Purchasing Decision, Covid-19

\section{INTRODUCTION}

The Covid-19 outbreak that began appearing in the city of Wuhan, Hubei Province, China in December 2019 was designated as a pandemic by the World Health Organization (WHO). Pandemic has caused chaos in the economic sector. The spread of Coronaviruses that have expanded to many parts of the world, including Indonesia, has also impacted economic growth in Indonesia. Both of the trade, investment and tourism sectors. Not only large industry, but pandemic Covid-19 also makes MSME in Indonesia start to worry. The impact of Covid-19 pandemic on MSME sector in Indonesia is a decrease in buying and selling activities.

As a result of the spread of Coronaviruses, Indonesian people are also more concerned with health and hygiene. A total of $44 \%$ of consumers claimed to be more often consuming health products, and $37 \%$ more often consume vitamin beverages. The vitamins and medicines industry actors capture these opportunities by increasing the advertising budget on television. For MSME entrepreneurs, the situation when creating opportunities to keep their business running and at the same time helps consumers to meet the needs of staying at home.

\author{
Setyo Riyanto \\ Associate Professor Mercu Buana University \\ Jakarta Indonesia
}

The Government's policy of conducting large-scale social restrictions (PSBB) in the centre of the pandemic Covid-19 has changed the consumption patterns of society. There are some new trends in consumer behaviour in purchasing decision-making due to the Covid-19 pandemic.

The first, due to social restrictions, consumers have switched online purchases from various needs such as medical supplies, clothing, and groceries purchased online. The second concern for health will be higher; consumers learn to consume healthy food, herbs, supplements and multivitamins, do meditation. So that MSME entrepreneurs adjust their performance to meet the needs of consumers.

Pandemic Covid-19 has also changed the way many companies and businesses operate significantly. With all the challenges that exist, the company certainly has no choice but to change the working culture as closely as possible to maintain the performance of their business because the Government's recommendation to implement social restrictions in the middle of society makes raw materials difficult to obtain because some companies take the Work From Home (WFH) policy resulting in a reduction in production capacity.

Working cultures such as Flexible Working Space can be interpreted as setting up employee work patterns that provide location flexibility during certain periods of time by maximizing information technology. If this Flexible Working Space is applied, then there will certainly be a trend adjustment of how it works, such as:

$>$ The emergence of new kinds of work of organizational Structures, corporations, and a lot of recent work types appear to accommodate human and rapidly changing technologies.

$>$ Multigenerational and diverse workforce.

$>$ Unconstrained structure and place of work can be done at any location and with flexible time. Worker ratios do not remain elevated.

$>$ A career determined by a worker, not a worker company has greater control over his career journey.

$>$ Digitalization and automation of technology simplify daily work and connects workers efficiently.

$>$ Data access and processing more and more data provides a better understanding of the behaviour and quality of workers. 
The second working culture, Remote Allowed, this remote stage allows approved employees of a company to work several (but not all) days out of the office. This type of company/organization allows some work to be done outside the office but still requires employees working from the office. In this Remote-Allowed stage, there will be $30 \%$ of employees who will do Flexible Working Space.

The third Hybrid Remote working culture, in turn, officers will get a timetable for work from the office and work from home. Later on, there will be teams consisting of employees working from the office and employees working from home. This will facilitate employees to coordinate while still providing flexibility in doing the job without having to travel to the office.

The last work culture of All Remote, all workers do its work from outside the office. Please be aware of being able to make an ape system Flexible Working Space need some requirements that must be fulfilled both from the side of mental readiness and performance history, as well as from the health condition.

In terms of mental readiness and performance history, there are at least ten basic requirements, such as being able to work independently, responsibly, responsively, highinitiative, adapt to new ways, have a good performance assessment result, have competence in operating systems and information technology, employee discipline reports, and the effectiveness of task execution. For this reason, this research will see how much impact business performance and culture work in MSME have on consumer purchases amid the Covid-19 pandemic.

\section{LITERATURE REVIEW}

\section{A. Business Performance}

Business performance becomes a key point to stay in the global era and during the Covid-19 pandemic. Business performance is the result of organizational objectives achieved through the effectiveness of strategy and Engineering (Fairoz, 2010). Many factors that determine the business performance of an organization are creating customers by marketing, innovating and economic productivity consisting of human resources, capital resources and physical resources. Some of these factors ultimately improve the business performance of the organization. According to Wibowo (2008), performance as a result of work or achievement and how the work process takes place. As for other opinions expressed by Amstrong and Baron in Wibowo (2008), performance is a result of work that has a relationship with the strategic objectives of the organization, customer satisfaction and contributes to the economy.

\section{B. Working Culture}

The culture of work is as a pattern of common ground assumptions learned by certain groups to address the problems of external adaptations and official internal integration and has worked well and is therefore taught or inherited to new members as a proper way of understanding, thinking and feeling related to those problems (Edgar H. Schein, 2010). Meanwhile, according to Sarplin in Susanto (2006), the working culture is a system of value, belief and habit with its formalized structure to produce norms of organizational behaviour.

Based on the definitions expressed by the experts, it can be concluded that the working culture is a fundamental pattern of values, expectations, habits and beliefs that are shared with all members of the organization as a guideline in carrying out tasks to achieve organizational objectives. (Robbins, 2006) there are five functions of working culture that is very important for the advancement of the organization, namely:

$>$ Culture serves as a boundary - determining boundaries.

$>$ We are delivering a feeling of identity for member organizations.

$>$ Simplify the broader commitment of one's individual interests.

$>$ Improve social system stability because it is a social adhesive that helps unify organizations.

$>$ As control and the rational mechanism that guides and establishes employee attitudes and behaviours.

\section{Consumer Purchase Decisions}

According to (Schiffman, Kanuk, 2004), the purchasing decision is the selection of two or more alternative purchasing decision options, meaning that one can make a decision, there should be some alternative options. The decision to buy can lead to how the process in that decision-making was done. As for (Kotler, 2005) states that: "Purchasing decision is a problem-solving process consisting of analyzing the needs and wishes, information retrieval, assessment of selection sources against purchasing alternatives, purchase decisions, and behaviour after purchase".

According to Kotler (2006), in making consumer decisions in buying goods and services are found several factors of consumer characteristics, the company's stimulation that includes products, prices, places and promotions as well as other stimulus conditions such as politics, economics, technology and culture. The customer's response to the stimulus will lead to a product's decision, a decision on a brand, a decision on the dealer and the time and number of purchases. The desire to buy arises as consumers feel interested and want to wear the products he sees, according to (Howard; Shay, 1998) The buying process will go through five stages, namely:

$>$ Fulfilment of Needs

$>$ Understanding needs

$>$ Process of searching for goods

$>$ Evaluation process

$>$ Purchase decision Making

A repeated purchase decision will be purchase Intentions. Purchase Intentions are defined as "the individual's judgment about buying a designated service again from the same company, taking into account his or her current situation and likely circumstances" (Hellier, 2003). 


\section{METHODOLOGY OF RESEARCH}

In this study used a quantitative approach to explaining the influence between business performance variables (X1) and working culture (X2) towards consumer purchase decisions (Y). The questionnaire was distributed to 122 respondents who were consumers in the service and culinary field. The data analysis techniques used are as follows:

\section{$>$ Validity Test}

A validity test is used to test which items are valid and which are invalid (Maida, 2017). The validity test in this study was done by comparing the $\mathrm{R}$ count value by the $\mathrm{R}$ table. If the calculated R-value is greater than $r$ table, then the questionnaire item is valid.

\section{Reliability Test}

The reliability test is used to determine which question items are used really reliably as measuring instruments. The method used in measuring the reliability of a questionnaire is to use Cronbach's Alpha method for each measured variable (Setiawan, 2016). Variables can be considered reliable when they have an alpha value greater than 0.60 (Riyanto, 2019).

\section{$>$ Multiple Linear Regression Analysis}

This analysis is used to determine the direction of the relationship between the dependent and independent variables, whether each variable is independently positive or negative. Additionally, this analysis is also used to predict the value of the dependent variable when there is an increase or decrease in an independent variable (Maida, 2017). The different forms of multiple linear regression equations used are as follows:

$$
\begin{array}{ll}
\mathbf{Y}=\mathbf{a}+\mathbf{b}_{1} \mathbf{X}_{\mathbf{1}}+\mathbf{b}_{2} \mathbf{X}_{\mathbf{2}}+\mathbf{e} \\
\mathrm{Y} & =\text { Purchase decision } \\
\mathrm{a} & =\text { Constant } \\
\mathrm{b}_{1} \ldots \mathrm{b}_{2} & =\text { Regression Coefficients } \\
\mathrm{X}_{1} & =\text { Business performance } \\
\mathrm{X}_{2} & =\text { Culture of work } \\
\mathrm{e} & =\text { Error }
\end{array}
$$

\section{Descriptive Analysis}

Descriptive analysis is used to analyze data by describing or describing the collected data so that the data presented can be easily understood and informative (Sholikhah, 2016). Descriptive hypothesis and statistical hypothesis can be compiled as follows:

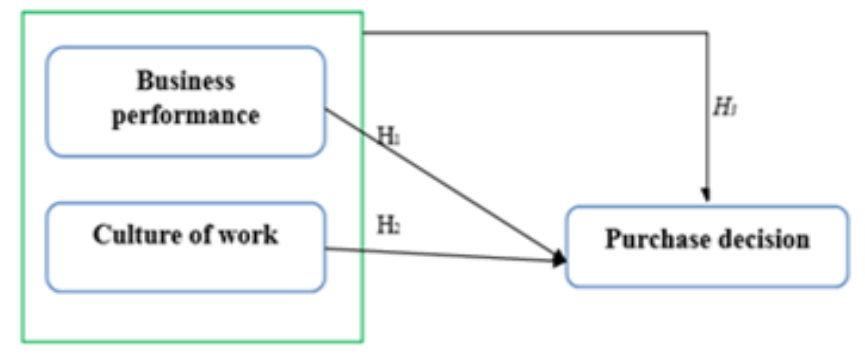

Fig 1:- Framework model

\section{Hypothesis}

H1: Business performance affects purchase decisions.

$H 2$ : Work culture influences purchasing decisions.

H3: Business performance and culture work to purchase decisions.

\section{RESULT AND DISCUSSION}

This research is conducted by spreading the questionnaire to 122 respondents who are consumers in the field of services and culinary who have a business in the field of service and culinary. The result is processed by using the Statistic 25 for Windows application. Characteristics of respondents who are customers in the field of service and culinary as well as judging by age, gender, and also education. The results of the descriptive analysis show that the majority of female-type respondents were 21-30 years old, with a percentage of $52 \%$. Respondents aged 31-40 years had a percentage of $23 \%$. Respondents aged 41-50 years have a percentage of $12 \%$. Respondents over 50 years old have a percentage of $11 \%$. The remaining respondents were less than 20 years old. In addition, the majority of respondents have a minimum S1 level of education. The disseminated questionnaire consists of 15 question items that are divided into three variables, namely business performance (X1), working culture (X2) and purchase decision (Y).

\section{Validity Test}

The validity test is used to test valid and invalid question items (Maida, 2017). In this study, the validity test was conducted by comparing the $R$ count value by the $R$ table. If the $R$ count value is greater than the $R$ table value, the questionnaire item is considered valid. Results from the validity test can be seen in the table below.

\begin{tabular}{|c|c|c|c|}
\hline Variable & count & $\mathbf{r}_{\text {table }}$ & Information \\
\hline $\begin{array}{c}\text { Business } \\
\text { Performance }\left(\mathrm{X}_{1}\right)\end{array}$ & $\begin{array}{c}0.544- \\
0.855\end{array}$ & 0.1779 & Valid \\
\hline $\begin{array}{c}\text { Working Culture } \\
\left(\mathrm{X}_{2}\right)\end{array}$ & $\begin{array}{c}0.303- \\
0.705\end{array}$ & 0.1779 & Valid \\
\hline $\begin{array}{c}\text { Purchase } \\
\text { Decision }(\mathrm{Y})\end{array}$ & $\begin{array}{c}0.401- \\
0.772\end{array}$ & 0.1779 & Valid \\
\hline
\end{tabular}

Table 1:- Validity test on Business performance (X1), working culture (X2), and purchase decision (Y)

Based on the table above, it can be seen that with a significance level of 5\% acquired $\mathrm{R}$ table value of 0.1786 . In the table, the validity test for the $\mathrm{X} 1$ variable that is a business-performance variable indicates that the variable has an $\mathrm{r}$ count value of $0544-0855$ where the value is greater than the $\mathrm{R}$ table value so that the $\mathrm{X} 1$ variable is considered valid. The validity test for a variable $\mathrm{X} 2$ that is a working culture indicates that the variable has an $r$ count value of $0303-0705$ where the value is greater than the table R-value so that the variable $\mathrm{X} 2$ is considered valid. Likewise with the validity test for variable $\mathrm{Y}$ that is a purchase decision variable has a value of $\mathrm{R}$ count of $0401-$ 0772 where the value is greater than the table $\mathrm{R}$-value so that the variable $\mathrm{Y}$ is considered valid. 


\section{Reliability Test}

The reliability test is used to demonstrate the level of reliability of the internal consistency by measuring the coefficient of Cronbach's Alpha where variables can be considered reliable when they have an Alpha value greater than 0.60 (Riyanto, 2019). The results of the reliability test. based on Cronbach's Alpha formula can be seen in the table below.

\begin{tabular}{|c|c|c|c|}
\hline Variable & $\begin{array}{c}\text { Reliability } \\
\text { Coefficient }\end{array}$ & $\begin{array}{c}\text { Critical } \\
\text { Point }\end{array}$ & Information \\
\hline $\begin{array}{c}\text { Business } \\
\text { Performance } \\
\left(\mathrm{X}_{1}\right)\end{array}$ & 0.769 & 0.6 & Reliable \\
\hline $\begin{array}{c}\text { Working } \\
\text { Culture }\left(\mathrm{X}_{2}\right)\end{array}$ & 0.669 & 0.6 & Reliable \\
\hline $\begin{array}{c}\text { Purchase } \\
\text { Decision (Y) }\end{array}$ & 0.656 & 0.6 & Reliable \\
\hline
\end{tabular}

Table 2:- The Result of Reliability Test

According to the table above, it can be seen that the working culture variable (X1), the competitive advantage (X2), and the performance of the business (Y) has a coefficient value greater than 0.60 with the value of each variable at 0769 for business performance variables (X1), 0669 for the Working culture variable (X2), and 0656 for the purchase decision variety ( $\mathrm{Y}$ From these results, all three variables can be.

\section{Multiple Linear Regression Analysis}

This analysis is used to determine the direction of the relationship between the dependent and independent variables, whether each variable is independently positive or negative. Additionally, this analysis is also used to predict the value of the dependent variable when there is an increase or decrease in an independent variable (Maida, 2017). The results of multiple linear regression analyses can be seen in the table below.

\begin{tabular}{|c|c|c|c|c|c|}
\hline \multicolumn{6}{|c|}{ Coefficients $\square$} \\
\hline & \multicolumn{2}{|c|}{ Unstandardized Coefficients } & \multirow{2}{*}{$\begin{array}{c}\text { Standardized } \\
\text { Coefficients } \\
\text { Beta } \\
\end{array}$} & & \\
\hline & $\mathrm{B}$ & Std. Error & & & \\
\hline (Constant) & 16.126 & 1.429 & & 11.285 & .000 \\
\hline $\begin{array}{l}\text { Business } \\
\text { Performance }\end{array}$ & .094 & .070 & .124 & 2.349 & .180 \\
\hline Working Culture & 128 & .062 & .189 & 2.046 & .043 \\
\hline
\end{tabular}

a. Dependent Variable: Purchase Decision

Table 3:- The Result of Reliability Test

Based on the table above can be written into the form of multiple linear regression equations as follows:

$$
Y=16.126+2.349 X_{1}+2.046 X_{2}
$$

According to the table above, it can be seen that the business performance variable $(\mathrm{X} 1)$ has a calculated t value of 2,349 with a table $\mathrm{T}$ value of 1.9801 . This indicates that the $\mathrm{X} 1$ variable has a significant influence on the purchase decision because the calculated $\mathrm{T}$ value is greater than the table $\mathrm{T}$ value. Whereas, the working culture variable (X2) has a calculated $t$ value of 2,046 with a table $T$ value of 1.9801 where it indicates that the variable $\mathrm{X} 2$ has a significant influence on the purchase decision because the calculated $\mathrm{T}$ value is greater than the table $\mathrm{T}$ value.

\begin{tabular}{|c|c|c|c|c|c|c|}
\hline \multicolumn{7}{|c|}{ ANOVA ${ }^{\square}$} \\
\hline \multicolumn{2}{|l|}{ Model } & Sum of Squares & df & Mean Square & $\mathrm{F}$ & Sig. \\
\hline & Regression & 49.781 & 2 & 24.891 & 4.060 & $.020^{\mathrm{a}}$ \\
\hline & Residual & 729.563 & 119 & 6.131 & & \\
\hline & Total & 779.344 & 121 & & & \\
\hline \multicolumn{7}{|c|}{ a. Predictors: (Constant), Business Performance, Working Culture } \\
\hline De & Variable: & se Decision & & & & \\
\hline
\end{tabular}

Table 4:- The Result of F-Test

Based on the table above indicates that the value of the calculated $F$ is 4,060 with a table $F$ value of 3.14 . This suggests that the working culture variables and competitive advantages have a significant (simultaneous) effect on the business performance variables as it has an $\mathrm{F}$ value count greater than the $\mathrm{F}$ table.

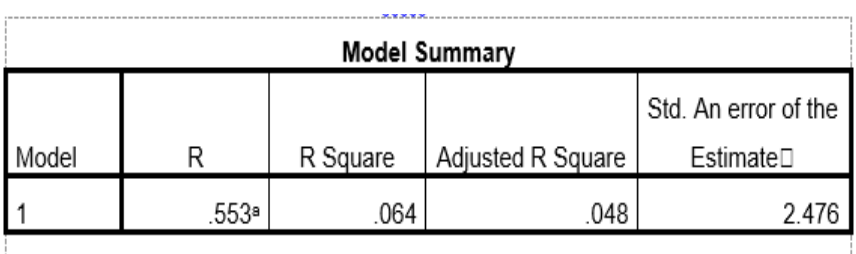

a. Predictors: (Constant), Business Performance, Working Culture

Table 5:- The Result of The Coefficient of Determination

From the table above we can get the coefficient of determination as follows:

$\mathrm{KD}=\mathrm{R}^{2} \times 100 \%$

$=(0.553)^{2} \times 100 \%$

$=31 \%$

Based on the above calculations it can be seen that the business performance variables (X1) and the working culture (X2) have a simultaneous effect of $31 \%$ on the purchase decision variable $(\mathrm{Y})$, while the remaining $69 \%$ is influenced by other factors not researched in this study.

\section{CONCLUSION}

Based on the results of research and discussion that has been done, several conclusions can be drawn, including:

There is a positive and significant influence on business performance variables against purchase decision variables. This is evidenced by the acquisition of a calculated $t$ value of 2,349 that is larger with a table $\mathrm{T}$ value of 1.9801 .

There is a positive and significant influence on the working culture variables against the purchase decision variables. This is evidenced by the acquisition of a calculated $t$ value of 2,046 that is larger with a table $\mathrm{T}$ value of 1.9801 . 


\section{REFERENCES}

[1]. Fairoz et al., 2010. Entrepreneurial Orientation and Business Performance of Small and Medium Scale Enterprises of Hambantota District Sri Lanka. Asian Social Science Vol 6 No 3 March 2010.

[2]. Hellier, Philip K, Gus Geursun, Rodney A. Carr, and John A. Rickard. 2003. Customer Repurchase Intention: A General Structural Equation Model. European Journal of Marketing.

[3]. Howard, J.A. and Shay, R.P. (1988) Measuring The effect of Marketing Information on Buying Intention. The Journal of Service Marketing, Vol.2, No.4 Fall, P.27-36,

[4]. Kotler, Philip, diterjemahkan oleh Hendra Teguh dan Ronny A. Rusli, 2005. Manajemen Pemasaran. Edisi Kesebelas Jidil I dan II . Indeks. Jakarta.

[5]. Kotler \& Amstrong. (2006). Principle of Marketing. United State: Pearson Prentice Hall.

[6]. Maida, M.T., Riyanto, S., dan Ali, H. 2017. Effect of Job Satisfaction and Leadership Style Towards Employee Productivity at PT Asuransi Umum Bumiputera Muda 1967. Saudi Journal of Business and Management Studies Vol-2: 157-168.

[7]. Riyanto, Setyo. 2019. The Impact of Leadership, Organizational Culture and Organizational Climate on Employee Job Satisfaction. Advances in Economics, Business, and Management Research vol. 120.

[8]. Robbins, Stephen P. dan Timothy A. Judge. 2008. Perilaku Organisasi Edisi ke-12, Jakarta: Salemba Empat.

[9]. Schein, Edgar H. (2010) Organizational Culture and Leadership. Fourth Edition.Jossey-Bass. A Wiley Imprint, Market Street. San Fransisco CA.

[10]. Schiffman \& Kanuk.2004. Perilaku Konsumen. Zulkifli Kasip (alih bahasa) Edisi Ketujuh. Penerbit PT. Indexs. Jakarta.

[11]. Setiawan, Z dan Rusdiansyah. 2016. Peranan Bauran Harga Terhadap Peningkatan Penjualan Alat Kesehatan. Jurnal Pilar Nusa Mandiri Vol 12 No 2.

[12]. Sholikhah, A. 2016. Statistik Deskriptif Dalam Penelitian Kualitatif. Komunika Vol. 10 No. 2, JuliDesember 2016.

[13]. Susanto, A.B., Gede Prama. Dkk. 2006. Strategi Organisasi. Yogyakarta: Amara Books.

[14]. Wibowo, Amin, 2008, "The Impact of Organisational Culture And Internal Corporate Governance On Organisational Performance In Indonesian Companies", Ph. D. Curtin University. 